\title{
Prevalence and risk factors of anaemia among ever-married women in Jordan
}

\author{
Rasha Arabyat, ${ }^{1}$ Ghaith Arabyat ${ }^{2}$ and Ghaith Al-Taani ${ }^{1}$
}

${ }^{1}$ Department of Pharmacy Practice, Faculty of Pharmacy, Yarmouk University, Irbid, Jordan. ${ }^{2}$ Jordanian Royal Medical Services, Amman, Jordan. (Correspondence to: Rasha Arabyat: rasha.arabyat@yu.edu.jo).

\begin{abstract}
Background: Anaemia is associated with poor health outcomes and is considered a serious public health problem particularly in low- and middle-income countries. Specific subgroups are at higher risk of anaemia, such as women of reproductive age.

Aims: This study examined the prevalence and risk factors of anaemia among ever-married women in Jordan using a secondary analysis of the Jordan Population and Family Health Survey.

Methods: This is a secondary analysis of data from a nationally representative sample of ever-married women aged 15-49 years that were tested for haemoglobin levels in the 2012 JPFHS. Anaemia was categorized according to the WHO criteria. Univariate and multivariate logistic regression analyses were used to investigate risk factors associated with anaemia.

Results: The prevalence of any anaemia was 37.3\%; specifically, 20\% had mild anaemia (haemoglobin 11.0-11.9 g/dl), 16.3\% had moderate anaemia (hemoglobin 8.0-10.9 g/dl) and 1\% had severe anaemia (haemoglobin $<8.0 \mathrm{~g} / \mathrm{dl}$ ). Factors that were associated with anaemia in the multivariate regression included urban women $(P=0.01)$, living in the north $(P=0.014)$ or south regions $(P=0.013)$ of Jordan, having multiple children $(P<0.001)$, being pregnant $(P<0.01)$, and using IUD as a contraceptive method $(P<0.001)$.

Conclusions: A high prevalence of anaemia among ever-married women of reproductive age in Jordan was noticed. The results emphasize the importance of urgent public health interventions to prevent anaemia in Jordan, particularly among high-risk subgroups.

Keywords: anaemia, Jordan Population and Family Health Survey (JPFHS), risk factors, public health, Jordan.

Citation: Arabyat R; Arabyat G; Al-Taani G. Prevalence and risk factors of anaemia among ever-married women in Jordan. East Mediterr Health J. 2019;25(8):543-552. https://doi.org/10.26719/emhj.18.074

Received: 05/03/18; accepted: 03/07/18

Copyright (C) World Health Organization (WHO) 2019. Some rights reserved. This work is available under the CC BY-NC-SA 3.0 IGO license (https:// creativecommons.org/licenses/by-nc-sa/3.o/igo).
\end{abstract}

\section{Introduction}

Anaemia among ever-married women has been identified as a major public health problem, particularly in low and middle-income countries (1). Anaemia is associated with poor immunity, cognitive dysfunction, decreased ability to work and reduced overall quality of life (2). In Jordan, the prevalence of anaemia has increased steadily over the past decade (3) despite the reduced global prevalence of anaemia worldwide (4). Jordan implemented various programmes for prevention and treatment of anaemia and other micronutrient deficiencies. These programmes included the national wheat flour fortification programmes with iron along with multiple other micronutrients. The Ministry of Health $(\mathrm{MoH})$ in Jordan also initiated routine screening programmes for pregnant women attending neonatal, prenatal, or postnatal care clinics for anaemia. Anaemic women are given a supplement that contains iron, zinc, and folic acid (5). Despite these interventions, the prevalence of iron-deficiency anaemia was not significantly improved during 2002-2010.

Apart from national and international reports, limited scientific research exists in Jordan on the determinants and prevalence of anaemia among ever-married women. Moreover, most of the studies conducted in Jordan to assess anaemia prevalence were either descriptive, based on a small sample size, or covered only limited geographical regions (6-8). The 2012 Jordan Population and Family Health Survey is the most recent populationbased survey that assesses anaemia and nutritional status in women of childbearing age using a nationally representative sample. However, the published findings of the 2012 JPFHS only included descriptive analysis and applied criteria for diagnosis of anaemia among women that is slightly different from the World Health Organization (WHO) cutoffs (9). The objective of this study is to examine the prevalence and risk factors of anaemia among ever-married women (15-49 years) in Jordan based on data from the 2012 JPFHS by using multivariate regression analysis and applying the most recent WHO cutoffs to categorize anaemia.

\section{Methods}

\section{Data source}

This is a secondary analysis of data from the 2012 Jordan Population and Family Health Survey, a nationally representative sample of 15190 households of the 12 governorates of Jordan. JPFHS data are collected in collaboration 
with the United States Agency for International Development (USAID; lead contributor), WHO and United Nations International Children's Emergency Fund (UNICEF) and other agencies (3). The survey was designed to collect information on ever-married women of reproductive age (15-49 years). The survey employed a two-stage cluster sampling procedure. In the first stage, 806 primary sampling units (PSUs) or clusters were selected with a probability proportional to the size of the cluster. In the second stage, a fixed number of 20 households were selected in each PSU. The sample was stratified into urban and rural areas, Badia and refugee camps domains. Participation in the survey was completely voluntarily as explained in the informed consent form obtained prior to data collection. The response rate was estimated to be $97 \%$. More information about sample design, sampling frame, methodology and organization of the survey is available in JPFHS/2012 final report (10). Authorization to use the dataset was gained from the DHS program in the United States of America.

\section{Measurement of haemoglobin level}

The JPFHS includes data on 11352 ever-married women aged 15-49 years. Haemoglobin level, as an estimate of the prevalence of anaemia, was measured in a subsample of two-thirds (6953 ever-married women) of the selected households in each PSU. A drop of capillary blood was taken in the field from the women to measure their haemoglobin level using the hemoCue instrument. In this method, the blood is drawn from the finger directly into a reagent-coated microcuvette, which is then inserted into a portable-battery operated photometer. Haemoglobin level is then displayed numerically in grams per deciliter (10).The hemoCue instrument is a valid and highly precise method to estimate the prevalence of anaemia at the population level and the results obtained by this instrument are similar to the standard laboratory methods for measurement of haemoglobin concentration $(11,12)$. Anaemia levels among women have been adjusted for the influence of altitude because higher altitude of the household location is associated with higher levels of haemoglobin to compensate for lower concentrations of oxygen. Smoking also increases haemoglobin level substantially. Therefore, haemoglobin level was also adjusted for smoking status for proper diagnosis of anaemia in smokers (10).

\section{Study variables}

Selection of variables included in the analysis was specified based on a review of the published literature pertaining to predictors/risk factors of anaemia among women in low-income countries. Variables included in the analysis were limited to those collected by the JPFHS. The primary outcome of interest for this study was anaemia level. Anaemia was categorized according to the WHO criteria (9). Anaemia in non-pregnant women was classified based on the measured haemoglobin level as: no anaemia (haemoglobin $\geq 12.0 \mathrm{~g} / \mathrm{dL}$ ), mild (haemoglobin = 11.0-11.9 g/dL), moderate (haemoglobin $=8.0-10.9) \mathrm{g} /$
$\mathrm{dL}$ ), and severe (haemoglobin $<8.0 \mathrm{~g} / \mathrm{dL}$ ) and in pregnant women was classified as: no anaemia (haemoglobin $\geq$ $11.0 \mathrm{~g} / \mathrm{dL}$ ), mild (haemoglobin = $10.0-10.9 \mathrm{~g} / \mathrm{dL}$ ), moderate (haemoglobin $=7.0-9.9 \mathrm{~g} / \mathrm{dL}$ ) or severe (haemoglobin $<7.0 \mathrm{~g} / \mathrm{dL}$ ) (9).

Several factors that might put women at risk of anaemia were assessed as risk factors for anaemia. These factors included demographic, socio-economic, and health-related factors. Household economic status was measured via the wealth index estimated from information on household assets. This index was used to reflect the relative wealth of the surveyed household and was stratified into five wealth quintiles (poorest, poor, middle, rich, and richest) (10). Body mass index (BMI) was used to reflect the overall nutritional status of women participating in the survey. BMI is a simple weight-to-height ratio calculated by dividing weight in kilogrammes by the height in metre square $(\mathrm{kg} /$ $\mathrm{m}^{2}$ ). Women were classified according to their BMI as underweight $\left(<18.5 \mathrm{~kg} / \mathrm{m}^{2}\right)$, normal $\left(18.5-24.9 \mathrm{~kg} / \mathrm{m}^{2}\right)$ and overweight $\left(\geq 25 \mathrm{~kg} / \mathrm{m}^{2}\right)$. Facing problems in accessing health care was hypothesized to be a risk factor for anaemia. In the 2012 JPFHS, women were asked about barriers that they might face in accessing health care. Women were considered to have problems in accessing health care if they had concerns about at least one of the following factors: not knowing where to go, not getting permission to go, not being able to get money needed for treatment, distance to the health facility, having to take transportation, not wanting to go alone and concern that there may not be a female health provider.

Additional independent variables incorporated in this analysis were age $(15-19,20-29,30-39$, or $40-49$ years); residence (rural, urban); region (central, north or south); Badia (Badia, non-Badia); camps (camp, noncamp); education (no education, elementary, preparatory, secondary, or higher education); number of children (o, 1, 2-3, 4-5, or 6+); maternity status (pregnant, breastfeeding, neither); using intrauterine device (IUD) (yes, no); and tobacco smoking (yes, no) (Table 1).

\section{Statistical analysis}

The effects of the different independent variables on women anaemia were estimated using multivariate logistic regression method using STATA statistical package, version 14.0 (11). Survey commands in STATA were used to apply sampling weights to get the prevalence of anaemia by severity level. In the bivariate analysis, possible significant predictors of anaemia were examined using chi-squared test $\left(\chi^{2}\right)$. Second, a multiple logistic model was built in which the anaemia level was analysed as a binary variable comparing no anaemia with having any level of anaemia (mild, moderate, or severe). Results from the multiple logistic regression are presented as adjusted odds ratios (AORs) with 95\% confidence intervals (CI) and $P$-values. Observations with missing data were excluded. The alpha significance level was set at 0.05 . 


\section{Ethical approval}

This is a secondary analysis of existing dataset with all identifying information of study participants removed. Before asking any question and before performing hemoglobin testing, informed consent was acquired from respondents, explaining the purpose of the study and the voluntary nature of participation.

\section{Results}

Prevalence of anaemia among ever-married women of the 7440 ever-married women that were eligible for haemoglobin testing, 6953 (93.5\%) were measured. The remaining eligible women were excluded from the analysis because they either refused to be measured ( $\mathrm{n}=$ $478,6.4 \%$ ) or were not present in the household ( $\mathrm{n}=9$, $0.12 \%$ ) at the time of measurement (Figure 1 ). The overall prevalence of anaemia among ever-married women in Jordan was $37.3 \%$. The prevalence of mild, moderate, and severe anaemia was $20 \%, 16.3 \%$, and $1 \%$ respectively. Table 1 demonstrates the weighted prevalence of anaemia by severity level as a function of selected characteristics. Prevalence of anaemia did not vary by education, wealth quintiles, BMI, tobacco smoking, difficulties in accessing health care, living in Badia or camps. The highest prevalence of anaemia was noticed among women who were having six or more children $(43.4 \%, n=1,569)$, using IUD $(42.6 \%, n=1,313)$, or pregnant $(40.2 \%, n=690)$ (Table 1$)$.
The results of multivariate regression analysis of the significant factors associated with anaemia are summarized in Table 2. Having six or more children was significantly associated with anaemia $(\mathrm{AOR}=1.54,95 \% \mathrm{CI}$ $=1.22-1.93, P<0.001, n=1,569)$. Being pregnant $(n=690)$ significantly increases the likelihood of anaemia (AOR = $1.26,95 \% \mathrm{CI}=1.06-1.51, P=0.009)$. Ever-married women who were using IUD $(n=1313)$ had higher odds of anaemia compared to those who were not using IUD (AOR $=1.38$, $95 \% \mathrm{CI}=1.21-1.57, P<0.001)$. Those residing in urban areas $(n=4940)$ were more likely to suffer from anaemia $(\mathrm{AOR}=1.17,95 \% \mathrm{CI}=1.05-1.31, \mathrm{P}=0.01)$ compared to those residing in rural areas $(n=2013)$. Lastly, women living in north $(n=2,516)$ and south regions $(n=1990)$ of Jordan had significantly greater odds of anaemia compared to those living in central regions $(n=2447)$ of Jordan $(\mathrm{AOR}=1.18,95 \% \mathrm{CI}=1.05-1.31, \mathrm{P}=0.01$ and $\mathrm{AOR}=1.26,95 \%$ $\mathrm{CI}=1.06-1.37, \mathrm{P}=0.013$ )

\section{Discussion}

In the current study, prevalence of anaemia and its associated risk factors among a representative sample of ever-married women aged 15 to 49 years in Jordan are investigated. The study, based on the 2012 JPFHS, revealed that anaemia is common among Jordanian women of reproductive age. The estimated prevalence rate of anaemia among ever-married women in Jordan (37\%) is only $3 \%$ lower than the $40 \%$ threshold determined by WHO for

Figure 1 Flow diagram of ever-married women aged 15-49 years who were measured for haemoglobin, 2012 JPFHS

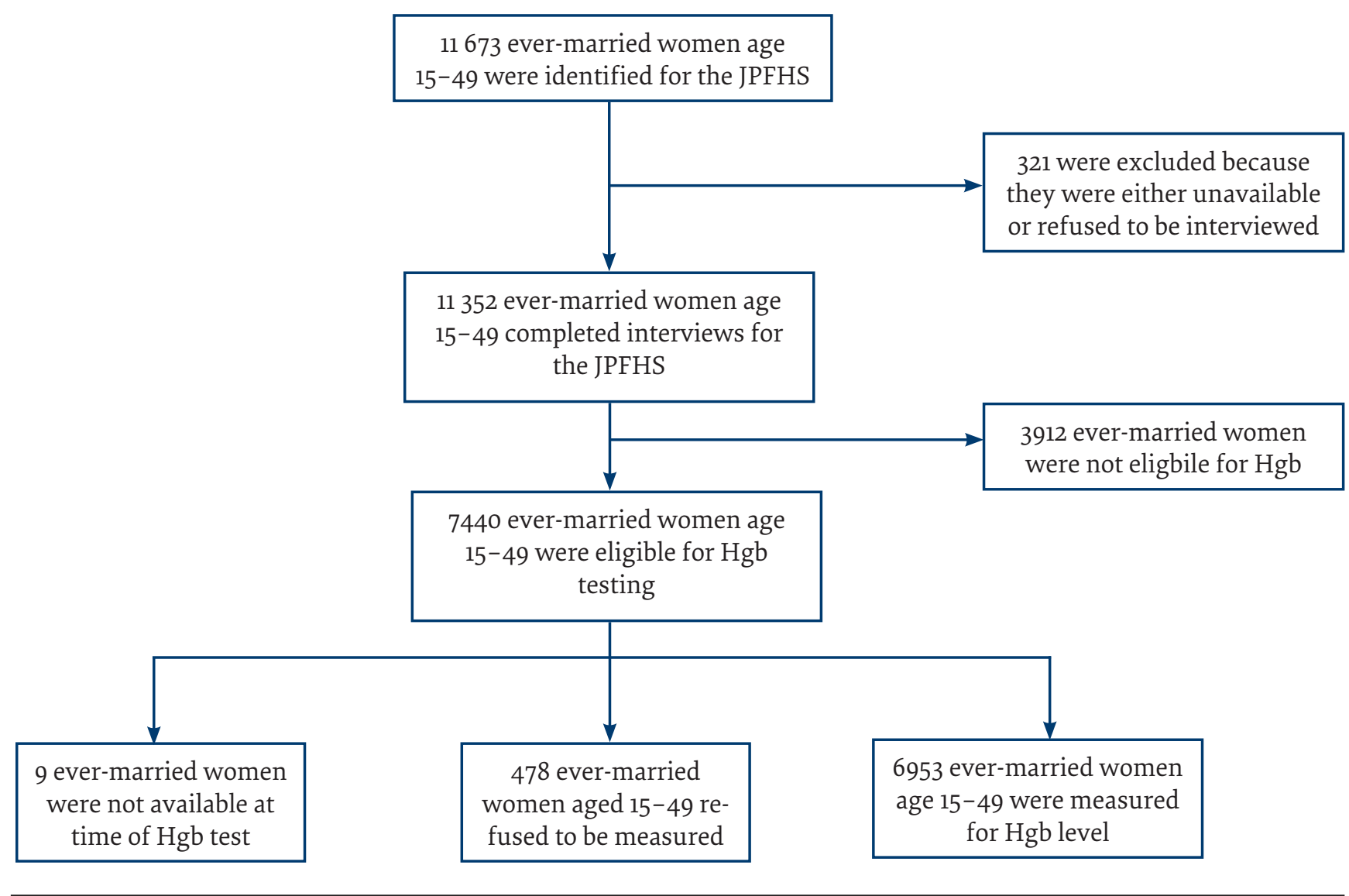


Table 1 Prevalence of anaemia among ever-married women aged 15-49 years by background characteristics, maternity status, and other selected characteristics, JPFHS 2012

\begin{tabular}{|c|c|c|c|c|c|c|}
\hline & & & emia status by $h$ & moglobin level & & \\
\hline & & $\begin{array}{c}\text { Any } \\
\text { anaemia (\%) }\end{array}$ & $\begin{array}{c}\text { Mild } \\
\text { anaemia (\%) }\end{array}$ & $\begin{array}{c}\text { Moderate } \\
\text { anaemia (\%) }\end{array}$ & $\begin{array}{c}\text { Severe } \\
\text { anaemia (\%) }\end{array}$ & P-value \\
\hline & Non-pregnant & $<12.0 \mathrm{~g} / \mathrm{dl}$ & $11.0-11.9 \mathrm{~g} / \mathrm{dl}$ & $8.0-10.9 \mathrm{~g} / \mathrm{dl}$ & $<8.0 \mathrm{~g} / \mathrm{dl}$ & \\
\hline & Pregnant & $<11.0 \mathrm{~g} / \mathrm{dl}$ & $10.0-10.9 \mathrm{~g} / \mathrm{dl}$ & $7.0-9.9 \mathrm{~g} / \mathrm{dl}$ & $<7.0 \mathrm{~g} / \mathrm{dl}$ & \\
\hline Characteristic & $\begin{array}{l}\text { Number of } \\
\text { Women (n) }\end{array}$ & & & & & \\
\hline Total & 6953 & 37.3 & 20.0 & 16.3 & 1 & \\
\hline Age (years) & & & & & & $<0.001$ \\
\hline $15-19$ & 152 & 31.7 & 20.1 & 11.3 & 0.2 & \\
\hline $20-29$ & 2034 & 35.8 & 21.8 & 13.9 & 0.1 & \\
\hline $30-39$ & 2665 & 38.8 & 21 & 17 & 0.8 & \\
\hline $40-49$ & 2102 & 37.0 & 17.2 & 17.8 & 2.0 & \\
\hline Residence & & & & & & 0.013 \\
\hline Rural & 2013 & 36.9 & 18.2 & 17.1 & 1.6 & \\
\hline Urban & 4940 & 37.4 & 20.4 & 16.1 & 0.9 & \\
\hline Region & & & & & & 0.215 \\
\hline Central & 2447 & 36.2 & 20.1 & 15.1 & 1.0 & \\
\hline North & 2516 & 38.8 & 19.7 & 18.1 & 1.1 & \\
\hline South & 1990 & 39.4 & 20.3 & 18.0 & 1.1 & \\
\hline Badia & & & & & & 0.618 \\
\hline Badia & 773 & $37 \cdot 3$ & 18.5 & 17.8 & 1.0 & \\
\hline Non-Badia & 6180 & 37.4 & 20.2 & 16.2 & 1.0 & \\
\hline Camps & & & & & & 0.671 \\
\hline Camp & 584 & 35.9 & 19.0 & 15.9 & 1.0 & \\
\hline Non-camp & 6369 & 37.4 & 20.1 & 16.3 & 1.0 & \\
\hline Education & & & & & & 0.384 \\
\hline No education & 251 & 31.9 & 14.5 & 17.0 & 0.4 & \\
\hline Elementary & 617 & 39.6 & 22.8 & 15.9 & 1.0 & \\
\hline Preparatory & 995 & 41.1 & 21.6 & 18.3 & 1.2 & \\
\hline Secondary & 2969 & 38.6 & 20.7 & 17.0 & 0.9 & \\
\hline Higher & 2121 & 32.9 & 17.8 & 14.1 & 1.0 & \\
\hline Wealth quintiles & & & & & & 0.774 \\
\hline poorest & 1672 & 38.6 & 19.3 & 18.6 & 0.8 & \\
\hline poor & 1813 & 39.0 & 21.7 & 15.9 & 1.5 & \\
\hline Middle & 1599 & 40.8 & 21.4 & 18.5 & 0.9 & \\
\hline rich & 1212 & 33.6 & 17.8 & 14.8 & 1.0 & \\
\hline richest & 657 & 33.1 & 19.6 & 12.7 & 0.8 & \\
\hline Number of children & & & & & & $<0.001$ \\
\hline 0 & 641 & 30.4 & 16.7 & 13.3 & 0.4 & \\
\hline 1 & 725 & 34.5 & 18.6 & 14.6 & 1.3 & \\
\hline $2-3$ & 2079 & 35.4 & 21.3 & 13.3 & 0.7 & \\
\hline $4-5$ & 1939 & 38.3 & 20.4 & 16.9 & 1.0 & \\
\hline $6+$ & 1569 & 43.4 & 19.7 & 22.2 & 1.5 & \\
\hline Maternity status & & & & & & $<0.001$ \\
\hline Pregnant & 690 & 40.2 & 26.1 & 14.0 & 0.1 & \\
\hline Breastfeeding & 1211 & 33.7 & 22.0 & 11.4 & 0.3 & \\
\hline Neither & 5052 & 37.7 & 18.8 & 17.6 & 1.3 & \\
\hline
\end{tabular}


Table 1 Prevalence of anaemia among ever-married women aged 15 - 49 years by background characteristics, maternity status, and other selected characteristics, JPFHS 2012 (concluded)

\begin{tabular}{|c|c|c|c|c|c|c|}
\hline \multirow[b]{5}{*}{ Characteristic } & \multicolumn{6}{|c|}{ Anaemia status by haemoglobin level } \\
\hline & & $\begin{array}{c}\text { Any } \\
\text { anaemia (\%) }\end{array}$ & $\begin{array}{c}\text { Mild } \\
\text { anaemia (\%) }\end{array}$ & $\begin{array}{c}\text { Moderate } \\
\text { anaemia (\%) }\end{array}$ & $\begin{array}{c}\text { Severe } \\
\text { anaemia (\%) }\end{array}$ & $P$-value \\
\hline & Non-pregnant & $<12.0 \mathrm{~g} / \mathrm{dl}$ & $11.0-11.9 \mathrm{~g} / \mathrm{dl}$ & $8.0-10.9 \mathrm{~g} / \mathrm{dl}$ & $<8.0 \mathrm{~g} / \mathrm{dl}$ & \\
\hline & Pregnant & $<11.0 \mathrm{~g} / \mathrm{dl}$ & $10.0-10.9 \mathrm{~g} / \mathrm{dl}$ & $7.0-9.9 \mathrm{~g} / \mathrm{dl}$ & $<7.0 \mathrm{~g} / \mathrm{dl}$ & \\
\hline & $\begin{array}{l}\text { Number of } \\
\text { Women }(n)\end{array}$ & & & & & \\
\hline Using IUD & & & & & & $<0.001$ \\
\hline Yes & 1313 & 42.6 & 19.5 & 21.8 & 1.3 & \\
\hline No & 5626 & 36.0 & 20.2 & 14.9 & 0.9 & \\
\hline BMI & & & & & & 0.939 \\
\hline$<18.5$ (thin) & 112 & 28.4 & 16.2 & 12.0 & 0.2 & \\
\hline $18.5-24.9$ (normal) & 1765 & 39.5 & 20.3 & 18.5 & 0.7 & \\
\hline $\begin{array}{l}\geq 25 \text { ( overweight and } \\
\text { obese) }\end{array}$ & 5076 & 36.6 & 20.0 & 15.5 & 1.1 & \\
\hline Tobacco smoking & & & & & & 0.998 \\
\hline Yes & 967 & 36.2 & 19.3 & 15.9 & 1.1 & \\
\hline No & 5986 & 37.5 & 20.2 & 16.3 & 1.0 & \\
\hline Problems in accessing healthcare & & & & & & 0.989 \\
\hline Yes & 4194 & 37.4 & 20.7 & 15.9 & 0.8 & \\
\hline No & 2759 & 37.0 & 18.8 & 16.9 & 1.3 & \\
\hline
\end{tabular}

classifying anaemia as a "severe public health problem" (12). For specific subgroups (pregnant women, those who use IUD, and high-parity women), the estimated anaemia rates are above the threshold of identifying anaemia as a severe public health problem. This prevalence has increased over the past decade from $29 \%$ of ever-married women in 2002 to $37.3 \%$ in 2012 (13). Despite the national wheat fortification programme, which was initiated in 2002 in Jordan, no significant improvement in the prevalence of iron-deficiency anaemia was noticed among a nationally representative sample of women aged 15-49 years between 2002 and 2012 (5). Accordingly, the government has to reconsider the cost-effectiveness of the national wheat fortification programme. One possible explanation for such disappointing results is the decreased access to foods that are rich in iron, such as red meat, because of economic crises that led to significant increases in food price index (5).

Results from our study show no significant association between anaemia and women's education and wealth, which are inconsistent with overall trends in non-industrialized and some industrialized countries (4). Anaemia is usually associated with disadvantaged populations where people of lower education and income are at increased risk for anaemia. Previous studies conducted in Tanzania (14), Mali (15), and India (16) showed higher risk of anaemia among non-educated and poor women. It is possible that non-educated and poor women have lower access to health information and healthcare facilities compared to educated and wealthy women. However, our analysis based on JPFHS show that there are no differences in access to health care between anaemic and non-anaemic women.

The highest prevalence of anaemia is found in pregnant women. Anaemia during pregnancy elevates the risk of maternal and neonatal morbidity and mortality, which are major causes of death in low and middle-income countries including Jordan (4). Causes for anaemia during pregnancy include nutritional deficiencies, bacterial and parasitic infections, and genetic disorders of the red blood cells such as thalassaemia (17). In Jordan, thalassaemia is one of the most common haemoglobinopathies, which may partly justify the high prevalence of anaemia among Jordanian pregnant women (18). The World Health Organization recommended the prenatal use of iron supplements in low and middle-income countries to overcome the high burden of anaemia among pregnant women (19). A comprehensive meta-analysis of randomized controlled trials suggested that iron use during pregnancy is associated with a significant reduction in the risk of low birth weight(19). To comply with WHO recommendations, and due to the high prevalence of anaemia among pregnant women, the ministry of health $(\mathrm{MoH})$ in Jordan initiated routine anaemia screening and treatment programmes for pregnant women attending antenatal clinics. Women who are found to have anaemia are given a combination of iron, zinc, and folic acid supplements. Given the high prevalence of anaemia among pregnant women in Jordan, routine supplementation programmes for all pregnant women (not only the anaemic ones) maybe more appropriate option as recommended by 
Table 2 Results from the multivariate logistic regression of factors associated with anaemia among ever-married women aged 15-49 years, Jordan 2012

\begin{tabular}{|c|c|c|c|c|c|}
\hline Variable & $\beta$ coefficient & Standard error & $\mathrm{AOR}^{*}$ & $95 \%$ CI & P-value \\
\hline \multicolumn{6}{|l|}{ Age (years) } \\
\hline $15-19$ & & & 1.00 & $0.71-1.48$ & 0.924 \\
\hline $20-29$ & 0.02 & 0.187 & 1.01 & $0.68-1.44$ & 0.894 \\
\hline $30-39$ & -0.03 & 0.193 & 0.98 & $0.78-1.70$ & 0.512 \\
\hline $40-49$ & 0.13 & 0.199 & 1.14 & & \\
\hline \multicolumn{6}{|l|}{ Residence } \\
\hline Rural & & & 1.00 & & \\
\hline Urban & 0.157 & 0.061 & 1.17 & $1.05^{-1.31}$ & 0.01 \\
\hline \multicolumn{6}{|l|}{ Region } \\
\hline Central & & & 1.00 & & \\
\hline North & 0.150 & 0.061 & 1.18 & $1.05-1.32$ & 0.014 \\
\hline South & 0.163 & 0.066 & 1.20 & $1.06-1.37$ & 0.013 \\
\hline \multicolumn{6}{|l|}{ Badia } \\
\hline Non-Badia & & & 1.00 & & \\
\hline Badia & -0.076 & 0.088 & 0.93 & $0.78-1.1$ & 0.39 \\
\hline \multicolumn{6}{|l|}{ Camps } \\
\hline Non-camp & & & 1.00 & & \\
\hline Camp & -0.139 & 0.097 & 0.87 & $0.72-1.1$ & 0.155 \\
\hline \multicolumn{6}{|l|}{ Education } \\
\hline No education & & & 1.00 & & \\
\hline Elementary & 0.137 & 0.159 & 1.15 & $0.84-1.57$ & 0.39 \\
\hline Preparatory & 0.193 & 0.153 & 1.21 & $0.90-1.64$ & 0.21 \\
\hline Secondary & 0.120 & 0.147 & 1.13 & $0.85-1.5$ & 0.41 \\
\hline Higher & 0.051 & 0.152 & 1.1 & $0.78-1.42$ & 0.74 \\
\hline \multicolumn{6}{|l|}{ Wealth quintiles } \\
\hline poorest & & & 1.00 & & \\
\hline poor & 0.087 & 0.072 & 1.1 & $0.95-1.26$ & 0.228 \\
\hline Middle & 0.127 & 0.077 & 1.14 & $0.98-1.3$ & 0.097 \\
\hline rich & -0.035 & 0.086 & 0.97 & $0.82-1.14$ & 0.685 \\
\hline richest & -0.022 & 0.107 & 0.98 & $0.79-1.21$ & 0.840 \\
\hline \multicolumn{6}{|l|}{ Number of children } \\
\hline 0 & & & 1.00 & & \\
\hline 1 & 0.04 & 0.119 & 1.04 & $0.82-1.31$ & 0.74 \\
\hline $2-3$ & 0.25 & 0.102 & 1.29 & $1.05-1.58$ & 0.013 \\
\hline $4-5$ & 0.33 & 0.110 & 1.39 & $1.12-1.72$ & 0.003 \\
\hline $6+$ & 0.44 & 0.117 & 1.54 & $1.22-1.93$ & $<0.001$ \\
\hline \multicolumn{6}{|l|}{ Maternity status } \\
\hline Neither pregnant/breastfeeding & & & 1.0 & & \\
\hline Pregnant & 0.23 & 0.089 & 1.26 & $1.06-1.51$ & 0.009 \\
\hline Breastfeeding & -0.035 & 0.072 & 0.97 & $0.84-1.11$ & 0.643 \\
\hline \multicolumn{6}{|l|}{ Using IUD } \\
\hline No & & & 1.00 & & \\
\hline Yes & 0.322 & 0.066 & 1.38 & $1.21-1.57$ & $<0.001$ \\
\hline \multicolumn{6}{|l|}{ BMI } \\
\hline$<18.5$ (thin) & & & 1.00 & & \\
\hline $18.5-24.9$ (normal) & 0.116 & 0.207 & 1.12 & $0.75-1.68$ & 0.573 \\
\hline$\geq 25$ (overweight and obese) & -0.03 & 0.204 & 0.97 & $0.65-1.44$ & 0.883 \\
\hline \multicolumn{6}{|l|}{ Tobacco smoking } \\
\hline No & & & 1.00 & & \\
\hline Yes & -0.002 & 0.074 & 0.99 & $0.86-1.15$ & 0.978 \\
\hline \multicolumn{6}{|l|}{ Problems in accessing healthcare } \\
\hline No & & & 1.00 & & \\
\hline Yes & -0.006 & 0.052 & 0.99 & $0.90-1.100$ & 0.909 \\
\hline
\end{tabular}

*AOR= Adjusted odds ratio. 
WHO and as practiced in other countries of the Region. These programmes, among others, would have the potential to improve the iron-status of pregnant women and subsequently reduce the overall prevalence of anaemia. However, not enough information exists on the exact number of pregnant women enrolled in these programmes, and therefore their full potential cannot be estimated accurately (5).

In this analysis, it was found that the prevalence of anaemia among women of reproductive age in Jordan also varied according to the geographical region. We found that living in north or south regions of Jordan is associated with a higher prevalence of anaemia compared to living in central regions. A previous study conducted among women over 15 years old in southern regions of Jordan estimated that more than half of the surveyed women reported having anaemia (haemoglobin < $12 \mathrm{~g} / \mathrm{dL}$ ) (7). Similar to our results, an analysis of the Haitian Demographic and Health Survey found that women living in urban areas are at greater risk for anaemia compared to living in rural areas (20). The authors of the Haitian study attributed this variation to the different types of food consumed by the urban and rural populations. People living in rural areas have more access to low-cost micronutrient-rich fruits and vegetables compared to those living in urban areas (20). Additionally, the food system in the urban areas changed over the past decade with more access to fast food that is poor in micronutrients (21). A previous study conducted among Bedouin schoolchildren in Jordan concluded that urbanization negatively impacted their micronutrient status and led to under-nutrition (8). Future research may investigate the impact of urbanization on the prevalence of anaemia among ever-married women in Jordan.

According to our analysis, increased age was found to be a significant predictor for anaemia in the bivariate but not in the multivariate analysis. Previous studies showed that ever-married women of older age have a higher risk of anaemia compared to younger women. Poor diet and the presence of other comorbidities may make older adults more susceptible to anaemia (22). Consistent with our findings, several other studies have confirmed that anaemia is common in older populations and its prevalence increases with advancing age (23-25). Earlier, anaemia was merely seen as a manifestation of underlying diseases, but recent evidence suggests that its presence alone is associated with an increased risk for death, coronary and cerebrovascular complications and reduced quality of life (26-28). Recent data from clinical practice suggest that anaemia is frequently underdiagnosed and treated in elderly populations. Underdiagnosis of anaemia in older persons may be due to misperceptions that anaemia is a natural phase of aging. Furthermore, symptoms of anaemia may be overlooked by the presence of comorbidities with similar clinical presentation (26). The presence of anaemia requires a thorough investigation to identify the underlying cause and treat the condition appropriately according to published guidelines for evaluation and management of anaemia in the elderly $(29,30)$.

Our analysis showed that the use of Intrauterine Device (IUD) increases the risk of anaemia independent from other factors. However, there is no question in the JPFHS to specify the exact type of IUD used. The use of copper-IUD as a contraceptive method may increase the risk of iron-deficiency anaemia by increasing menstrual loss. There is inconsistent data regarding the risk of anaemia with IUD use. For example, a hospital-based study conducted in Egypt found that IUD users had significantly lower levels of haemoglobin compared to non-users or users of other contraceptive methods (31). In contrast, a longitudinal prospective study conducted among Iranian women found that there was no significant increase in anaemia cases among copper-IUD users (32). A recent meta-analysis of studies that measured haemoglobin changes among copper-IUD users found significant decreases of haemoglobin level after one year of use, but these changes were not sufficient to induce anaemia in women with no history of anaemia (33). Another systematic review found no significant changes of haemoglobin level among anaemic women who used copper-IUD for up to one year (34). Given the increase use of IUD devices in low and middle-income countries including Jordan, and the possible increase in the risk of iron-deficiency anaemia, it is recommended that iron supplements should be provided for copper-IUD users in family planning clinics.

Lastly, results from our study indicated that having six or more children (high-parity) significantly increases the risk of anaemia. A retrospective cohort study conducted in Oman among pregnant women found that high parity women have three times greater risk for developing anaemia compared to low-parity women (less than five pregnancies with gestational age $\geq 20$ weeks) and the risk increases in a dose-response mode with increasing level of parity (35). Another cross-sectional study conducted in Indonesia showed that multiparous (having two or more live birth) women had 58\% greater risk of becoming anaemic compared to nulliparous (has never given birth) women $(P<0.001)(36)$. One possible explanation for such an increased risk of anaemia is that high parity exposes women to more frequent episodes of haemorrhage which may occur before, during or after each delivery (35). Additionally, repeated pregnancy, delivery and breastfeeding reduce the level of several micronutrients in the body, including iron (37). Inadequate replacement of the lost iron with each pregnancy may increase the risk of anaemia in high parity women (36).

The main strengths of this study included using a nationally representative sample of ever-married women in Jordan aged 15-49 years, which allows for generalization of results and measuring haemoglobin level directly without relying on medical records or selfreported information. Additionally, this study applied the most recent WHO cutoffs of haemoglobin level for defining anaemia and used a multivariate regression analysis to study risk factors of anaemia. However, our study has some limitations. First, due to the cross- 
sectional nature of the study it is not possible to establish causality between the different risk factors and anaemia. Second, the Jordan JPFHS included questions about micronutrients intake and types of food and liquid consumed by children only but not women. BMI was used as an indication of women's nutritional status but no significant association was found with anaemia. Using BMI as a proxy for nutritional status is not accurate since it does not differentiate between lean muscle and fat tissue (38). Third, most of variables measured in the study were self-reported, which make the results of study subject to recall and social desirability biases. Fourth, measuring serum haemoglobin concentration at the population level as an indicator of anaemia is considered the most reliable method as compared to other clinical measures $(39,40)$. However, anaemia is a multifaceted condition that requires obtaining medical and family histories as well as physical examination for accurate diagnosis. A small number of healthy people may fall below the reference range and some individuals with an underlying condition may fall within the normal reference range for haemoglobin concentration. Lastly, data used for analysis were collected more than five years ago. Nevertheless, at the time of writing, the most recent data available for Jordan from the Demographic and Health Survey website was for 2012.

\section{Conclusion}

Anaemia is common among ever-married women aged 15-49 years in Jordan. We identified several important risk factors associated with anaemia. Results from our study enhance the current knowledge about the prevalence, distribution, and risk factors of anaemia among women in Jordan and raised anaemia as a public health concern that requires urgent and expanded countrywide intervention.

\section{Funding: None.}

Conflict of interests: None declared.

\section{Prévalence et facteurs de risque d'anémie chez les femmes mariées ou l'ayant été en Jordanie}

\section{Résumé}

Contexte : L'anémie est associée à des conséquences néfastes sur la santé et constitue un grave problème de santé publique, en particulier dans les pays à revenu faible ou intermédiaire. Des sous-groupes spécifiques présentent un risque d'anémie plus élevé, comme par exemple les femmes en âge de procréer.

Objectifs : La présente étude a examiné la prévalence et les facteurs de risque de l'anémie chez les femmes mariées ou l'ayant été en Jordanie au moyen d'une analyse secondaire de l'enquête de santé familiale de la population jordanienne.

Méthodes : Il s'agit d'une analyse secondaire des données obtenues à partir d'un échantillon national représentatif de femmes mariées ou l'ayant été, âgées entre 15 et 49 ans, dont le taux d'hémoglobine a été mesuré dans le cadre de l'enquête de santé familiale de la population jordanienne réalisée en 2012. L'anémie a été classée selon les critères fixés par l'OMS. Des analyses de régression logistique univariée et multivariée ont été conduites afin d'analyser les facteurs de risque associés à l'anémie.

Résultats : La prévalence de l'anémie était de 37,3\%; plus précisément, $20 \%$ présentaient une légère anémie (taux d'hémoglobine compris entre 11,0 et $11,9 \mathrm{~g} / \mathrm{dl}$ ), $16,3 \%$ une anémie modérée (taux d'hémoglobine compris entre 8,0 et $10,9 \mathrm{~g} / \mathrm{dl}$ ) et $1 \%$ une anémie sévère (taux d'hémoglobine $<8,0 \mathrm{~g} / \mathrm{dl}$ ). Les facteurs associés à l'anémie dans la régression multivariée étaient les suivants: femmes vivant en milieu urbain ( $p=0,01)$, dans les régions du nord $(p=0,014)$ ou du sud $(p=0,013)$ de la Jordanie, ayant plusieurs enfants $(p<0,001)$, étant enceintes $(p<0,01)$, et ayant recours au dispositif intra-utérin comme méthode contraceptive $(p<0,001)$.

Conclusions : Une prévalence élevée de l'anémie a été constatée chez les femmes en âge de procréer mariées ou l'ayant été en Jordanie. Les résultats soulignent l'importance des interventions urgentes de santé publique visant à prévenir l'anémie en Jordanie, en particulier parmi les sous-groupes à risque élevé.

$$
\begin{aligned}
& \text { معدل انتشار فقر الدم وعوامل الخطر الخاصة به بين النساء المتزوجات حاليًا أو اللاتي تزوجن من قبل في الأردن } \\
& \text { رشا عربيات، غيث عربيات، غيث الطعاني }
\end{aligned}
$$

$$
\begin{aligned}
& \text { الخلفية: يرتبط فقر الدم بالمخرجات الصحية الضعيفة ويعد مشكلة خطيرة بالنسبة للصحة العامة، لا سيّما في البلدان منخفضة ومتوسطة الدخل. }
\end{aligned}
$$

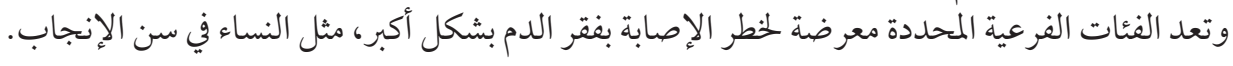

$$
\begin{aligned}
& \text { الأهداف: فحصت هذه الدراسة معدل انتشار فقر الدم وعو امل الخطر المرتبطة به بين النساء المتزوجات حاليًا أو اللاتي تزوجن من قبل في الأردن، }
\end{aligned}
$$

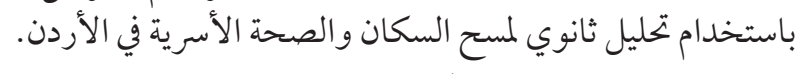

$$
\begin{aligned}
& \text { طرق البحث: يعد هذا تحليلً ثانويًا للبيانات المأخوذة من عينة مثثلة وطنية للنساء المتزوجات حاليًا أو اللاتي تزوجن من قبل واللاتي تراوحت }
\end{aligned}
$$




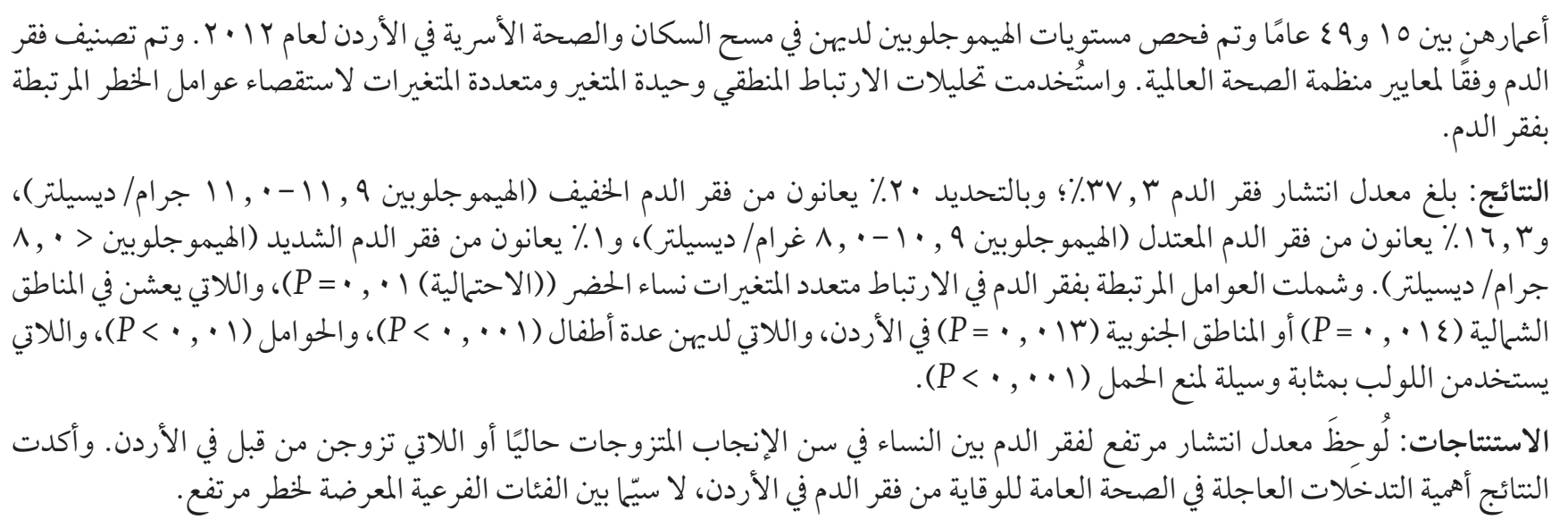

\section{References}

1. Balarajan Y, Ramakrishnan U, Özaltin E, Shankar AH, Subramanian S. Anaemia in low-income and middle-income countries. Lancet. 2011;378(9809):2123-35. http://dx.doi.org/10.1016/So140-6736(10)62304-5

2. Haas JD, Brownlie T 4th. Iron deficiency and reduced work capacity: a critical review of the research to determine a causal relationship. J Nutr. 2001;131(2):676S-90S. http://dx.doi.org/10.1093/jn/131.2.676S

3. The DHS Program - Jordan. Standard DHS, 2012 [Internet]. [cited 2017 Jun 30]. Available from: http://dhsprogram.com/what-wedo/survey/survey-display-403.cfm

4. Stevens GA, Finucane MM, De-Regil LM, Paciorek CJ, Flaxman SR, Branca F, et al. Global, regional, and national trends in haemoglobin concentration and prevalence of total and severe anaemia in children and pregnant and non-pregnant women for 1995-2011: a systematic analysis of population-representative data. Lancet Glob Health. 2013;1(1):e16-25. http://dx.doi.org/10.1016/ S2214-109X(13)70001-9

5. Serdula M, Nichols E, Aburto N, Masa'd H, Obaid B, Wirth J, et al. Micronutrient status in Jordan: 2002 and 2010. Eur J Clin Nutr. 2014;68(10):1124-8. http://dx.doi.org/10.1038/ejcn.2014.100

6. Al-Mehaisen L, Khader Y, Al-Kuran O, Abu Issa F, Amarin Z. Maternal anemia in rural Jordan: room for improvement. Anemia. 2011;2011:381812. http://dx.doi.org/10.1155/2011/381812

7. Abu-Moghli FA, Khalaf IA, Tokiko S, Atsuko I, Nabolsi MM, Al-Sharairi BA. Reproductive and non-reproductive health status of women aged 15 years and above in southern Jordan. East Mediterr Health J. 2012 May;18(5):417-25.

8. Khatib IMD, Elmadfa I. High prevalence rates of anemia, vitamin A deficiency and stunting imperil the health status of Bedouin schoolchildren in North Badia, Jordan. Ann Nutr Metab. 2009;55(4):358-67. http://dx.doi.org/10.1159/000258632

9. World Health Organization. Haemoglobin concentrations for the diagnosis of anaemia and assessment of severity. Geneva: World Health Organization; 2011 (http://www.who.int/vmnis/indicators/haemoglobin/en/).

10. Department of Statistics. Jordan population and family health survey 2012. Calverton, MD: ICF International; 2013 (https:// dhsprogram.com/pubs/pdf/FR282/FR282.pdf).

11. StataCorp. 2013. Stata Statistical Software: Release 13. College Station, TX: StataCorp LP.

12. World Health Organization. Iron deficiency anaemia: assessment, prevention and control: a guide for programme managers. Geneva: World Health Organization; 2001 (https://www.who.int/nutrition/publications/micronutrients/anaemia_iron_deficiency/WHO_NHD_01.3/en/).

13. Macro. Jordan population and family health survey 2002. Calverton, Maryland, MD: Department of Statistics/Jordan and ORC Macro; 2003 (http://www.dhsprogram.com/publications/publication-FR138-DHS-Final-Reports.cfm).

14. Wilunda C, Massawe S, Jackson C. Determinants of moderate to severe anaemia among women of reproductive age in Tanzania: analysis of data from the 2010 Tanzania demographic and health survey. Trop Med Int Health. 2013;18(12):1488-97. http://dx.doi. org/10.1111/tmi.12199

15. Ngnie-Teta I, Kuate-Defo B, Receveur O. Multilevel modelling of sociodemographic predictors of various levels of anaemia among women in Mali. Public Health Nutr. 2009;12(09):1462-9. http://dx.doi.org/10.1017/S1368980008004400

16. Ghosh S. Exploring socioeconomic vulnerability of anaemia among women in eastern Indian States. J Biosoc Sci. 2009;41(06):763-87. http://dx.doi.org/10.1017/So021932009990149

17. Breymann C. Iron deficiency anemia in pregnancy. In Elsevier; 2015. p. 339-47.

18. Hamamy HA, Al-Allawi NA. Epidemiological profile of common haemoglobinopathies in Arab countries. J Community Genet. 2013;4(2):147-67. http://dx.doi.org/10.1007/s12687-012-0127-8

19. Haider BA, Olofin I, Wang M, Spiegelman D, Ezzati M, Fawzi WW. Anaemia, prenatal iron use, and risk of adverse pregnancy 
outcomes: systematic review and meta-analysis. BMJ. 2013;346 jun21 3:f3443. http://dx.doi.org/10.1136/bmj.f3443

20. Heidkamp RA, Ngnie-Teta I, Ayoya MAA, Stoltzfus RJ, Mamadoultaibou A, Durandisse EB, et al. Predictors of anemia among haitian children aged 6 to 59 months and women of childbearing age and their implications for programming. Food Nutr Bull. 2013 Dec;34(4):462-79. http://dx.doi.org/10.1177/156482651303400411

21. Konstantyner T, Roma Oliveira TC, de Aguiar Carrazedo Taddei JA. Risk Factors for Anemia among Brazilian Infants from the 2006 National Demographic Health Survey. Anemia. 2012;2012:850681. http://dx.doi.org/10.1155/2012/850681

22. Fairweather-Tait SJ, Wawer AA, Gillings R, Jennings A, Myint PK. Iron status in the elderly. Mech Ageing Dev. 2014;136-137:228. http://dx.doi.org/10.1016/j.mad.2013.11.005

23. Patel KV. Epidemiology of anemia in older adults. Semin Hematol. 2008 Oct;45(4):210-7 http://dx.doi.org/10.1053/j.seminhematol.2008.06.006

24. Berliner N. Anemia in the elderly. Trans Am Clin Climatol Assoc. 2013;124:230.

25. Zakai NA, Katz R, Hirsch C, Shlipak MG, Chaves PH, Newman AB, et al. A prospective study of anemia status, hemoglobin concentration, and mortality in an elderly cohort: the Cardiovascular Health Study. Arch Intern Med. 2005;165(19):2214-20. http:// dx.doi.org/10.1001/archinte.165.19.2214

26. Balducci L, Ershler W, Krantz S. Anemia in the elderly-clinical findings and impact on health. Crit Rev Oncol Hematol. 2006;58(2):156-65. http://dx.doi.org/10.1016/j.critrevonc.2005.09.003

27. Eisenstaedt R, Penninx BW, Woodman RC. Anemia in the elderly: current understanding and emerging concepts. Blood Rev. 2006;20(4):213-26. http://dx.doi.org/10.1016/j.blre.2005.12.002

28. Woodman R, Ferrucci L, Guralnik J. Anemia in older adults. Curr Opin Hematol. 2005;12(2):123-8.

29. Goodnough LT, Schrier SL. Evaluation and management of anemia in the elderly. Am J Hematol. 2014;89(1):88-96.

30. Andrès E, Serraj K, Federici L, Vogel T, Kaltenbach G. Anemia in elderly patients: new insight into an old disorder. Geriatr Gerontol Int. 2013;13(3):519-27.

31. Hassan EO, El-Hussinie M, El-Nahal N. The prevalence of anemia among clients of family planning clinics in Egypt. Contraception. 1999;60(2):93-9. http://dx.doi.org/10.1016/So010-7824(99)00066-9

32. Behboudi-Gandevani S, Imani S, Moghaddam-Banaem L, Roudbar-Mohammadi S. Can intrauterine contraceptive devices lead to VulvoVaginal Candidiasis (VVC) andanemia in Iranian new users? Sex Reprod Healthc. 2015;6(1):40-3. http://dx.doi. org/10.1016/j.srhc.2014.09.003

33. Lowe RF, Prata N. Hemoglobin and serum ferritin levels in women using copper-releasing or levonorgestrel-releasing intrauterine devices: a systematic review. Contraception. 2013;87(4):486-96. http://dx.doi.org/10.1016/j.contraception.2012.09.025

34. Tepper NK, Steenland MW, Marchbanks PA, Curtis KM. Hemoglobin measurement prior to initiating copper intrauterine devices: a systematic review. Contraception. 2013;87(5):639-44. http://dx.doi.org/10.1016/j.contraception.2012.08.008

35. Al-Farsi YM, Brooks DR, Werler MM, Cabral HJ, Al-Shafei MA, Wallenburg HC. Effect of high parity on occurrence of anemia in pregnancy: a cohort study. BMC Pregnancy Childbirth. 2011;11(1):7. http://dx.doi.org/10.1186/1471-2393-11-7

36. Opitasari C, Andayasari L. Young mothers, parity and the risks of anemia in the third trimester of pregnancy. Health Sci J Indones. 2015;6(1):7-11.

37. Farooq A, Rauf S, Hassan U, Sadiq N. Impact of multi parity on iron content in multiparous women. J Ayub Med Coll Abbottabad. 2011;23(2):12-9.

38. Gurunathan U, Myles P. Limitations of body mass index as an obesity measure of perioperative risk. Br J Anaesth. 2016 Mar;116(3):319-21. http://dx.doi.org/10.1093/bja/aev541

39. Neufeld L, García-Guerra A, Sánchez-Francia D, Newton-Sánchez O, Ramírez-Villalobos MD, Rivera-Dommarco J. Hemoglobin measured by Hemocue and a reference method in venous and capillary blood: a validation study. Salud Publica Mex. 2002 Jun;44(3):219-27. http://dx.doi.org/10.1590/S0036-36342002000300005

40. Gwetu TP, Chhagan MK. Evaluation of the diagnostic accuracy of the HemoCue device for detecting anaemia in healthy schoolaged children in KwaZulu-Natal, South Africa. South Afr Med J. 2015 Jul;105(7):596-9. http://dx.doi.org/10.7196/SAMJnew.7919 